\title{
Efficacy of PDT in vulvar LS treatment based on immunohistochemical analysis of CD3, CD4, CD8, CD57, Granzyme B and Fascin expression
}

\author{
Efektywność terapii fotodynamicznej u pacjentek z liszajem twardzinowym sromu na podstawie \\ immunohistochemicznej analizy ekspresji CD3, CD4, CD8, CD57, granzymu B oraz fascyny
}

\author{
Anita Olejek ${ }^{1}$, Katarzyna Olszak-Wąsik ${ }^{1}$, Katarzyna Stęplewska², Stanisław Horák ${ }^{1}$, Jacek Zamłyński ${ }^{1}$, \\ Iwona Kozak-Darmas ${ }^{1}$, Andrzej Gabriel ${ }^{2}$
}

${ }^{1}$ Department of Gynecology, Obstetrics and Oncological Gynecology, Medical University of Silesia, Bytom, Poland;

Head of Department: Prof. Anita Olejek, MD, Phd

${ }^{2}$ Department of Histopathology, Medical University of Silesia, Zabrze, Poland;

Head of Department: Prof. Andrzej Gabriel, MD, Phd

Przegląd Menopauzalny 2013; 2: 155-158

\section{Summary}

Background: Lichen sclerosus (LS) is an immune-mediated chronic dermatosis of perimenopausal women. Inflammatory infiltration has been suggested as a potential cause of LS changes in epidermis and dermis. Photodynamic therapy (PDT) is a specific noninvasive treatment based on detection and subsequent selective destruction of LS-affected tissues that are marked by a photosensitizer. Immunomodulatory and cytotoxic effects of PDT are responsible for inducing several immunologic reactions which leads to inflammatory condition improvement.

The aim of the study was to determine the efficacy of photodynamic therapy for genital LS in correlation to protein expression involved in inflammatory infiltration - CD3, CD4, CD8, CD57, Granzyme B and Fascin.

Material and methods: A group of patients has been treated for active LS disease, diagnosis was histologically confirmed in skin biopsies. The skin biopsies were taken and analyzed with antibodies: CD3, CD4, CD8, CD57, Granzyme B and Fascin before and after PDT treatment.

Results: The study shows the efficacy of PDT in LS treatment including changes to CD3, CD4, CD57, Fascin, Granzyme $B$ and the lymphocytic infiltration in skin sections. The proliferation index of CD4 did not differ before and after PDT.

Conclusions: The PDT is a very effective therapeutic method in LS treatment.

Key words: lichen sclerosus, vulvar, PDT.

\section{Streszczenie}

Wstęp: Liszaj twardzinowy (LS) jest przewlekłą dermatozą z kręgu chorób immunologicznych spotykaną w grupie kobiet w wieku okołomenopauzalnym. W obrębie naskórka i skóry objętej zmianami o typie LS stwierdza się obecność nacieków zapalnych. Nieinwazyjną metodą leczenia tego schorzenia jest terapia fotodynamiczna (PDT), która dzięki zastosowaniu fotouczulacza pozwala na wykrycie i selektywne niszczenie obszarów tkanki zajętej liszajem twardzinowym. Immunomodulujące oraz cytotoksyczne efekty działania PDT są odpowiedzialne za wzbudzanie reakcji immunologicznych prowadzących do zmniejszenia stanu zapalnego.

Cel pracy: Celem pracy była próba określenia efektywności PDT w przypadkach liszaja twardzinowego sromu w zależności od ekspresji związanych z procesem zapalnym: CD3, CD4, CD8, CD57, granzymu B oraz fascyny.

Materiat i metody: Badaniem objęto grupę pacjentek z liszajem twardzinowym sromu, potwierdzonym w badaniu histopatologicznym wycinków ze sromu. W wycinkach tych oceniano ekspresję CD3, CD4, CD8, CD57, granzymu B oraz fascyny przed zastosowaniem PDT oraz po jej zastosowaniu.

Wyniki: Wykazano zmniejszoną ekspresję CD3, CD8, CD57, fascyny i granzymu B po zastosowaniu terapii PTD oraz zmniejszenie nacieku limfocytarnego w wycinkach ze sromu. Indeks proliferacji CD4 nie różnił się istotnie przed zastosowaniem PDT i po jej zastosowaniu.

Wnioski: Terapia fotodynamiczna jest wysoce efektywną metodą leczenia liszaja twardzinowego sromu.

Stowa kluczowe: liszaj twardzinowy, srom, terapia fotodynamiczna. 


\section{Introduction}

Lichen sclerosus (LS) is a chronic dermatosis of an unclear etiology. Most commonly it occurs in the anogenital area [1]. This disease affects mainly perimenopausal women, however, it is also seen in younger females and among men. Atrophy of skin and mucosa in LS causes itching, burning, sexual problems, dysuria and painful defecation.

The etiology of LS is still unclear. Genetic, autoimmunological and infectious factors are thought to be involved in LS development [2]. Recent studies confirm that T-cells (CD3+, CD4+, CD8+, CD57+), B-cells, complement fractions, immunoglobulins, specific autoantibodies and NK cells participate in inflammatory infiltration in LS-affected tissues $[3,4]$. The lymphocytic infiltrate of LS biopsies contains between $1.4 \%$ and $21 \%$ of T-cells with monoclonally rearranged T-cell receptor gamma-chain gene [2]. The presence of cytotoxic T-cells is connected with the chronic inflammation and cicatrisation [5]. Some authors reported on a higher Granzyme B expression in LS [4].

Granzymes belong to a family of serine proteases. There are three main groups of granzymes depending on their substrate specificity. All granzymes are synthesized as zymogens. Granzyme B is regarded to be the most powerful member of the family [6]. A granzyme expression is observed in NK cells and T cytotoxic cells. It was proven that granzyme B is also expressed on non-lymphocytic cells [7].

The name fascin comes from its ability to form bundles with $\mathrm{F}$ actin. Fascin is found to be necessary in cell-to-cell interactions, cells' migration and adhesion between cells and extracellular matrix. Its expression depends on the cell and tissue type. In physiological conditions, normal epithelium shows low or no fascin expression. This protein plays a significant role in cells' migration and it is regarded an essential factor of carcinogenesis and metastasis [8, 9].

The presence of TCR receptor, CD2, CD3 and CD4 or CD8 is the common feature of T lymphocytes subpopulation. On more than $90 \%$ of Th lymphocytes (T helpers), CD4 is found and most of the Tc lymphocytes (T cytotoxic) possess CD8 [10].

Natural killer cells activation depends on CD56, CD16 and CD57 expression. The group of NK cells is divided into immunoregulatory cells NK CD56++ and cytotoxic CD 56+/-. NK CD56++ are involved in the processes of antigen presenting and of $\mathrm{T}$ lymphocytes subpopulation formation [11].

A perfect LS treatment method has not been found yet. Potent topical steroids are found to be pharmacological treatment of choice. An alternative treatment includes sex hormone and retinoids usage, and surgical treatment in the case of extensive cicatrisation. The pharmacological and surgical methods are mostly ineffective [12, 13].
Photodynamic diagnosis (PDD) and then photodynamic therapy (PDT) are the treatment modalities of proven efficacy. The treatment is performed after topical application of the photosensitizer. In light irradiated tissues, singlet oxygen is produced. The cytotoxic effect of singlet oxygen leads to the tissue damage due to cell necrosis or apoptosis [13].

The aim of our study was to investigate the efficacy of photodynamic therapy (PDT) in vulvar LS and to analyze CD3, CD4, CD8, CD57, Granzyme B and Fascin expression before and after PDT application.

\section{Material and methods}

The study population consisted of a group of 100 women with histologically confirmed LS in vulvar biopsies. The average age in the group was 54 years (ranging from 45 to 62 years). All patients primarily underwent some pharmacological treatment (topical steroids of a potent or super-potent category, emollients and other additional medicines) without clinical or histological effects and showed active vulvar skin lesions. All patients had vulvar bacterial samples taken. In the case of abnormal results, they were treated according to the antibiogram. In all cases of infections, inflammatory factors were excluded. Two to three months after pharmacological treatment had been finished all patients underwent 10 courses of PDT. PhotoDyn 505 halogen lamp was used. The study protocol contained a course of PDT every second week. 5\% 5-aminolevulinic acid (ALA) was used as a photosensitizer and was applied three hours before each illumination.

Multiple punch biopsies were taken before PDT and 6 weeks after the $10^{\text {th }}$ course of the photodynamic therapy. Tissues were fixed in $10 \%$ formaldehyde and embedded in paraffin. Then, $5 \mu \mathrm{m}$ thick slices were hematoxylin-eosin stained according to the standard procedure. In immunohistochemical analysis monoclonal antibodies were used. Monoclonal antibodies used in this study are presented in Table I.

Markers were determined by the 3-stage immunohistomorphometric analysis ABC (Avidyn-Biotyn-Complex). Immunohistochemical staining was performed according to the manufacturer's instructions.

The expression of proteins was compared with a control tonsil tissue. For tissue evaluation, light microscope BX51 was used and the immune reaction had been estimated by 2 independent pathologists in a double blind trial.

Inflammatory infiltrations in the dermis were assessed semi-quantitatively using a four-point scale: 0 - no inflammation, 1 - small grade infiltration, 2 - medium grade infiltration, 3 - high grade infiltration.

The expression of CD3+, CD4+, CD8+, T lymphocytes, Granzyme B and CD57+ cells in the inflammatory infiltration of the dermis was scored semi-quantitatively using a six-point scale: 0 - lack of cells, 1 - single 
cells, 2 - less than $10 \%$ of cells, $3-11 \%$ to $30 \%$ of cells, $4-31 \%$ to $60 \%$ of cells, $5-61 \%$ to $100 \%$ of cells.

Fascine expression in dendritic cells was assessed semi-quantitatively using a four-point scale: 1 - negative, $2-1 \%$ to $10 \%$ positive, $3-10 \%$ to $50 \%$ positive, 4 - more than $50 \%$ positive.

All data were analyzed using Statistica 8.0PL version software. After verifying sample distribution normality by Shapiro-Wilk's test, Wilcoxon matched pairs test was performed to compare the parameters before and after PDT. Spearman nonparametric correlation was calculated. For statistical analysis the median was used to evaluate the change of CD3, CD4, CD8, Granzyme B, CD57 and Fascin before and after treatment. The level of significance ( $p$ value) was set at 0.05 for all tests. Our research was supported by grant NN-6-277/06. The study was approved by the Local Ethical Committee of the Medical University of Silesia, and written informed consent was obtained from all participants.

\section{Results}

Median age in a group of 100 women was 54 years (ranging from 45 to 62 years). First LS symptoms appeared at the median age of 53 years. The age of 57 years is a median age of the patients during their first ambulatory examination in the Clinic of Vulvar Diseases, Department of Gynecology, Obstetrics and Gynecological Oncology. All biopsies in a study group were characterized by localized dense lymphocytic tissue infiltration with a typical LS picture. After 10 courses of PDT, persistence of LS was confirmed in 38 cases (38\%). In histological images atrophic epidermis, subepidermal vacuolization, a band-like hyaline material in the superficial dermis and an underlying lymphocytic infiltrate were observed. Other 62 biopsies were described as vulvitis chronica, which was recognized as remission.

Inflammatory infiltrations in the dermis were assessed semi-quantitatively using a 4-stage scale. Detailed results are presented in Table I.

Table II shows the results of immunohistochemical analysis of CD3+, CD4+, CD8+, CD57+ cells, Granzyme B and Fascin expression.

Spearman rank correlation test $(p<0.005)$ has shown a significant positive correlation between inflammatory infiltrations and CD57 $(R=0.17)$, inflammatory infiltrations and Fascin $(R=0.21), C D 3+$ and CD8+ $(R=0.12), \mathrm{CD} 3+$ and Fascin $(R=0.20), \mathrm{CD} 8+$ and CD57+ $(R=0.33), \mathrm{CD} 8+$ and Fascin $(R=0.28)$.

The concomitant autoimmune diseases (thyroid gland disease, vitiligo, diabetes, autoimmune arthritis, psoriasis, allergy) have no influence on our results.
Tab. I. Lymphocytic infiltration before and after PDT

\begin{tabular}{lccccccc}
\hline & \multicolumn{3}{c}{ Before PDT } & \multicolumn{2}{c}{ After PDT } & Change & $\begin{array}{c}p \\
\text { value }\end{array}$ \\
\cline { 2 - 5 } & mean & SD & mean & SD & $\%$ & valuen \\
\hline $\begin{array}{l}\text { Inflammatory } \\
\text { infiltration }\end{array}$ & 1.85 & 0.77 & 1.49 & 0.69 & -19 & 0.001 \\
\hline
\end{tabular}

Tab. II. Results of immunohistochemical analysis of CD3+, CD4+, CD8+, CD57+ cells, Granzyme B and Fascin expression

\begin{tabular}{lccccccc}
\hline & \multicolumn{2}{c}{$\begin{array}{c}\text { Value before } \\
\text { PDT }\end{array}$} & \multicolumn{2}{c}{$\begin{array}{c}\text { Value after } \\
\text { PDT }\end{array}$} & $\begin{array}{c}\text { Change } \\
\%\end{array}$ & $p$ value \\
\cline { 2 - 5 } & mean & SD & mean & SD & & \\
\hline CD3 & 3.87 & 0.97 & 3.40 & 1.13 & -12 & $<0.001$ \\
\hline CD4 & 1.89 & 0.97 & 1.91 & 1.04 & 1 & 0.779 \\
\hline CD8 & 3.00 & 1.11 & 2.07 & 1.08 & -31 & $<0.001$ \\
\hline CD57 & 2.39 & 1.00 & 1.72 & 0.78 & -28 & $<0.001$ \\
\hline $\begin{array}{l}\text { Granzy- } \\
\text { me B }\end{array}$ & 1.48 & 0.69 & 1.23 & 0.60 & -17 & 0.005 \\
\hline Fascin & 2.77 & 0.93 & 2.34 & 0.76 & -16 & $<0.001$ \\
\hline
\end{tabular}

\section{Discussion}

Lichen sclerosus with its predilection for the genital skin is a rare chronic autoimmune skin disorder with distinctive dermal sclerosis and usually very thin, atrophic epidermis. This accounted for the old name "lichen sclerosus et atrophicus".

Many authors described the presence of inflammatory infiltration in LS skin biopsies using specific monoclonal antibodies [5, 8]. Typical inflammatory infiltrate of LS contains numerous epidermotropic CD3+, CD8+, CD57+ cells, increased intraepidermal HLA-DR+ cells, and in dermal infiltrate CD8+, CD57+, CD68+, HLA-DR+. In some authors' opinion, there is a predominance of the CD8 subpopulation in inflammatory infiltrations in tissues with LS [14].

Our research focused on PDT efficacy in decreasing numbers of inflammatory cells. We observed a decreased expression of CD3+, CD8+, CD57+ after PDT. A diminished number of those cells is the evidence for PDT efficacy in obtaining LS remission. Gross et al. identified in dermal LS many cytotoxic lymphocytes, i.e. CD8+ and CD67+ [5]. It is suspected that CD8+ and CD57+ expansion results from the excessive antigen exposure and is related with dermal sclerosis, viral infections, autoimmune diseases, neoplasms and sclerosing graft versus host reaction [14]. According to Chattopadhyay et al., CD57+ expression in T cells and NK cells is correlated with the Granzyme B expression, what could be a sufficient proof of the CD57 cytolytic potential [15]. Numerous CD8+ and CD57+ cells may be either the mediators in LS development or the consequence of the disease [14].

In the performed research, the expression of CD4+ before and after PDT was analyzed. The results showed no statistically significant difference. T reg cells CD4+CD25+ 
comprise $5-10 \%$ T cells CD4+. CD4+ regulatory T cells inhibit the effector lymphocytes proliferation and proinflammatory cytokines secretion. They control and suppress an exaggerated autoimmune response, especially in relation to autoantigens. Recent studies of CD4+ T cells with constant CD25+ (receptor for alpha chain of IL-2) expression suggest that they may act as peripheral tolerance guards [16]. In Regauer's opinion, the involution of changes observed in LS could be the consequence of the CD4+CD25+ $T$ reg cells inhibitory influence and also of the increased IL-10 production and decreased ROI (reactive oxygen intermediate) production in granulocytes [2]. Our results confirmed the presence of diminished inflammatory infiltrates in LS tissues after PDT. We did not notice any influence on CD4+ expression.

In some authors' opinion, CD8 T cells presence and the expression of Granzyme B molecules suggests cell-mediated immune cytotoxicity [17]. Cell-mediated immune cytotoxicity is responsible for pathological transformation in dermis and epidermis. This results in keratinocytes destruction and finally cells apoptosis [5]. In performed research, PDT caused a statistically significant decrease in Granzyme B expression. Granzymes expression is observed in lymphoid and non-lymphoid cells [7]. A higher Granzyme B expression was reported in viral diseases (EBV, CMV, HIV-1, Dengue fever), Neisseria meningitidis infection and Plasmodium falciparum infection. Granzymes are involved in atherosclerosis processes and in autoimmune diseases [7, 18]. It was noticed that Granzyme B participates in the formation or in the destruction of autoimmune epitopes. Structural changes in autoantigens observed during cell death in processes dependent on cell cytotoxicity are thought to be characteristic features of the systemic autoimmune diseases [18]. In presented research, concomitant autoimmune diseases did not influence the obtained results.

Fascin is a globular protein engaged in the antigen presenting. Qualtrough observed a higher Fascin expression in colon tissues among patients with colitis ulcerosa and Leśniowski-Crohn disease [19]. The expression was increased especially in repaired tissues. In neoplastic transformation, an increased Fascine expression correlates with poor survival $[9,19]$. UVB is a well-known factor that inhibits an immune response in dermis changing the antigen presenting cells' function and generating antigen tolerance in CD4+ cells. UVB suppresses Fascin expression that leads to the cells' cytoskeleton rearrangement and diminished antigen presenting in dendritic and Langerhans cells [20]. A Fascin expression in LS is the evidence for $T$ cell local activation and expansion. A decreased Fascin expression in our research after PDT $(p<0.001)$ proves the reduced pathologic inflammatory response.

Photodynamic therapy (PDT) is a promising method of LS treatment [13]. It is based on the detection and subsequent selective destruction of changed tissues that are marked by a photosensitizer (5-ALA). In the per- formed study, LS remission after PDT was obtained in $62 \%$ of patients. We did not notice any side effects.

\section{Conclusions}

Our data reveal effectiveness of PDT in decreasing inflammatory infiltration and CD3+, CD8+, CD57+, Granzyme B and Fascin expression in LS tissues. Although PDT gives us a new opportunity in LS treatment, there are still some questions concerning time between photosensitizer application and illumination beginning and also the length of the treatment period.

\section{References}

1. Bergstrom KG, Mengden SJ, Kamino H, Ramsay D. Extragenital lichen sclerosus et atrophicus. Dermatol Online J 2008; 14: 23.

2. Regauer S. Immune dysregulation in lichen sclerosus. Eur J Cell Biol 2005; 84: 273-7.

3. Carli P, Cattane A, Pimpinelli M, et al. Immunohistochemical evidence of skin immune system involvement in vulvar lichen sclerosus et atrophicus. Dermatologica 1991; 182: 18-22.

4. Hunger RE, Brönnimann M, Kappeler A, et al. Detection of perforin and granzyme B mRNA expressing cells in lichen sclerosus. Exp Dermatol 2007; 16: 416-20.

5. Gross T, Wagner A, Ugurel S, et al. Identification of TIA-1+ and granzyme B+ cytotoxic T cells in lichen sclerosus et atrophicus. Dermatology 2001; 202: 198-202.

6. Trapani JA. Granzymes: a family of lymphocyte granule serine proteases. Genome Biology 2001; 2: REVIEWS 3014.1-7.

7. Anthony DA, Andrews DM, Watt SV, et al. Functional dissection of the granzyme family: cell death and inflammation. Immunol Rev 2010; 235: 73-92.

8. Kureishy N, Sapountzi V, Prag S, et al. Fascins and their roles in cell structure and function. Bioessays 2002; 24: 350-61.

9. Zhao Q, Shen JH, Shen ZY, et al. Phosphorylation of fascin decreases the risk of poor survival in patients with esophageal squamous cell carcinoma. J Histochem Cytochem 2010; 58: 979-88.

10. Jakóbisiak M. Populacje i subpopulacje limfocytów. In: Immunologia. Gołąb J, Jakóbisiak M, Lasek W (eds.). Wyd. Naukowe PWN Press, Warszawa 2002; 94-101.

11. Kopeć-Szlęzak J, Podstawka U. Biologia komórek NK. Onkol Pol 2007; 10: 115-9.

12. Rolfe KJ, Crow JC, Reid WM, et al. The effect of topical corticosteroids on Ki67 and p53 expression in vulval lichen sclerosus. Br J Dermatol 2002; 147: 503-8.

13. Hillemanns $P$, Untch $M$, Pröve $F$, et al. Photodynamic therapy of vulvar lichen sclerosus with 5-aminolevulinic acid. Obstet Gynecol 1999; 93: 71-4.

14. Carlson JA, Grabowski R, Chichester P, et al. Comparative immunophenotypic study of lichen sclerosus: epidermotropic CD57+ lymphocytes are numerous - implications for pathogenesis. Am J Dermatopathol 2000; 22: 7-16.

15. Chattopadhyay PK, Betts MR, Price DA, et al. The cytolytic enzymes granyzme $A$, granzyme $B$, and perforin: expression patterns, cell distribution, and their relationship to cell maturity and bright CD57 expression. J Leukoc Biol 2009; 85: 88-97.

16. Lewkowicz P, Lewkowicz N, Tchórzewski H. CD4+CD25+ T regulatory cells in pathophysiology and therapy of immunologic diseases. Postepy Hig Med Dosw (Online) 2005; 59: 371-6.

17. Al-Alwan MM, Rowden G, Lee TD, West KA. Fascin is involved in the antigen presentation activity of mature dendritic cells. J Immunol 2001; 166: 338-45.

18. Darrah E, Rosen A. Granzyme B cleavage of autoantigens in autoimmunity. Cell Death Differ 2010; 17: 624-32.

19. Qualtrough D, Smallwood K, Littlejohns D, Pignatelli M. The actin-bundling protein Fascin is overexpressed in inflammatory bowel disease and may be important in tissue repair. BMC Gastroenterol 2011; 11: 14

20. Sugihara A, Okamoto $H$, Horio T. Effects of UVB on fascin expression in dendritic cells and Langerhans cells. J Dermatol Sci 2005; 40: 177-85. 